\title{
Characterization of Phenolic Compounds of Ulva rigida (Chlorophycae) and Its Antioxidant Activity
}

\section{Sana Mezghani ${ }^{1 *}$, Dezső Csupor ${ }^{2}$, Ines Bourguiba ${ }^{1}$, Judit Hohmann², Mohamed Amri ${ }^{1}$ and Mohamed Bouaziz ${ }^{3}$}

${ }^{1}$ Laboratory of Functional Neurophysiology and Pathology, Research Unit UR/11ES09, Department of Biological Sciences, Faculty of Science of Tunis, Tunis El Manar University, Tunis, Tunisia.

${ }^{2}$ Department of Pharmacognosy, University of Szeged, Hungary.

${ }^{3}$ Laboratory of Electrochimistry and Environnement, École Nationale d'Ingénieurs de, Sfax BP (1173) 3038, University of Sfax, Sfax, Tunisia.

\section{Authors' contributions}

This work was carried out in collaboration between all authors. Authors SM, DC and JH designed the study, performed the statistical analysis, wrote the protocol and wrote the first draft of the manuscript.

Authors SM and IB performed the experiments. Authors SM, MA and MB managed the analyses of the study and the literature searches. All authors read and approved the final manuscript.

Article Information

DOI: 10.9734/EJMP/2016/22935

Editor(s):

(1) Marcello Iriti, Professor of Plant Biology and Pathology, Department of Agricultural and Environmental Sciences, Milan State University, Italy.

Reviewers:

(1) Carmen Lizette Del Toro Sanchez, Universidad De Sonora, Mexico. (2) Ogunwande Isiaka Ajani, Lagos State University, Lagos, Nigeria. (3) Yongchun Zhu, Shenyang Normal University, China. (4) Boguslaw Lipinski, Harvard Medical School, Boston, USA. Complete Peer review History: http://sciencedomain.org/review-history/12687

\section{Original Research Article}

Received $5^{\text {th }}$ November 2015 Accepted $18^{\text {th }}$ November 2015 Published $16^{\text {th }}$ December 2015

\section{ABSTRACT}

Ulva rigida is a worldwide distributed green alga and is commenly used for human nutrition. Extracts of this seaweed were shown anti-hypercholestierinemic, antioxidant and antihyperglycemic activities. The antioxidant effect was often ascribed to the presence of a huge amount of polyphenols. The aim of this study was to characterise by high-performance liquid chromatography-electrospray ionisation mass spectrometry (HPLC-ESI-MS) the phenolic molecules present in extracts obtained from $U$. rigida. The antioxidant activities of different extracts were evaluated in vitro by DPPH assay and on HeLa cells culture. 
Keywords: Ulva rigida; LC/MS; phenolic compounds; antioxidant; cytotoxicity.

\section{INTRODUCTION}

Ulva rigida is a very common green marine seaweed distributed worldwide that is commonly used as a popular food ingredient in Asian countries as well as in North and South America $[1,2]$. The high protein, lipid, mineral and vitamin content of marine $U$. rigida have encouraged its extensive use as a dietary supplement for humans and animals and as an organic fertilizer $[3,4]$. Moreover, U. rigida has shown biological activities that are related to the presence of polyphenols [3,5,6], polysaccharides [3], terpenoids [3], fatty acids [3,5] and vitamins [3]. Several studies have demonstrated its antihyperglycemic [7,8], anti-hypercholestierinemic [7,8], anti-bacterial [5], anti-genotoxic [5], antioxidant [9] and immunostimulating activities $[10,11]$. In particular, $U$. rigida has received much attention as novel sources of natural antioxidants. Previous investigation on the phytochemistry suggested that $U$. rigida extracts produced large amounts of phenolic compounds $[5,6]$. However, until now there is no report focused in the chemical identification of those molecules. The aim of this study was to identify by High-performance liquid chromatographyelectrospray ionisation mass spectrometry (HPLC-ESI-MS) the main phenolic molecules present in the different extracts obtained from $U$. rigida in order to evaluate the correspondant phenolic profile. The evaluation of the free radical-scavenging properties, cytotoxicity and cytoprotective action of $U$. rigida extracts are also investigated. These data will offer a strong framework for new discoveries, particularly the pharmaceutical, cosmetic and agri-food processing industries.

\section{MATERIALS AND METHODS}

\subsection{Chemicals and Reagents}

Foetal bovine serum, L-glutamine, RPMI 1640, penicillin-streptomycin solution, phosphatebuffered saline (Gibco-BRL, France); dimethyl sulfoxide (DMSO) (Sigma, France); 5-6chloromethyl 2',7'-dichlorodihydrofluorescein diacetate (Molecular probes, USA); Hydrogen peroxide $\left(\mathrm{H}_{2} \mathrm{O}_{2}\right)$ (Pharmaghreb, Tunisia).

\subsection{Algal material}

Ulva rigida was collected from a shore of RasDjebel region in Tunisia. The algae were successively washed with water. The sample was botanically identified and a voucher specimen was deposited in the Laboratory of Functional Neurophysiology and Pathology (LFNP. URA 02).

\subsection{Algal Extract Preparation}

A fresh sample of $U$. rigida $(1 \mathrm{~kg})$ was mixed with $4 \mathrm{~L}$ of distilled water and sonicated. The mixture was then ground with an electric mortar and pressed. The resultant liquids $(4.8 \mathrm{~L})$ were pooled and subjected to chloroform and ethyl acetate extractions. The obtained extracts (chloroform, ethyl acetate, water) were concentrated with a rotary evaporator, freeze dried and stored until use. Approximately $15 \mathrm{ml}$ of water extract was hydrolysed by $\mathrm{H}_{2} \mathrm{SO}_{4}(2 \mathrm{M}$, $\left.8 \mathrm{~h}, 1^{\circ} \mathrm{C}\right)$ to allow glycoside separation. The obtained hydrolysate was neutralised, filtered and concentrated under vacuum. The methanol extract was obtained by using air-dried powdered $U$. rigida $(5 \mathrm{~g})$. The obtained solution was filtered through Whatman No. 1 paper and then evaporated at reduced pressure by rotary evaporator.

\subsection{Total Phenolic Determination}

The total phenolic contents in different extracts (ethyl acetate, methanol, water, hydrolysis water) were determined by the Folin-Ciocalteu method [12]. The total phenolic content was expressed as gallic acid equivalents (GAE) (mg/g of dry weight).

\subsection{DPPH Free-radical Scavenging Activity}

The effect of the extracts on DPPH (2,2-diphenyl1-picrylhydrazyl) radicals scavenging was estimated using a spectrometric method [13]. The test compound concentration providing $50 \%$ inhibition $\left(\mathrm{IC}_{50}\right.$ expressed in $\left.\mu \mathrm{g} \cdot \mathrm{mL}^{-1}\right)$ was calculated from the graph of the inhibition percentage plotted against the extract concentration. Butylated hydroxytoluene (BHT) was used as the positive control.

\subsection{Cell Culture and Treatment}

HeLa cells were maintained in RPMI medium containing $2 \mathrm{mM} \mathrm{L-glutamine,} \mathrm{10 \%} \mathrm{Foetal} \mathrm{Bovine}$ Serum (FBS) and $100 \mathrm{U} / \mathrm{ml}$ of antibiotic solution in a humidified $5 \% \mathrm{CO}_{2}$ incubator at $37^{\circ} \mathrm{C}$. The cells were grown in 24-well microplates until 70 - 
$80 \%$ confluence. Different concentrations (250, $350,400,500$ and $1000 \mu \mathrm{g} / \mathrm{ml}$ ) of the water extract of $U$. rigida and/or $\mathrm{H}_{2} \mathrm{O}_{2}(10,100,1000$ and $10000 \mu \mathrm{M}$ ) were added to the cells and incubated for $4 \mathrm{~h}$.

\subsection{Cytotoxicity Assay}

5-6-chloromethyl 2',7'-dichlorodihydrofluorescein diacetate $\left(\mathrm{CM}-\mathrm{H}_{2}\right.$ DCFDA $)$ was used as an intracellular esterase substrate to indicate cell integrity[14]. The $\mathrm{CM}-\mathrm{H}_{2} \mathrm{DCFDA}$ assay solution was freshly made by adding $15 \mu \mathrm{l}$ of $\mathrm{CM}$ $\mathrm{H}_{2}$ DCFDA stock solution ( $5 \mathrm{mg} / \mathrm{ml}$ DMSO, $-2^{\circ} \mathrm{C}$ ) to $1700 \mu \mathrm{l}$ of RPMI. The culture medium was removed from the microplate wells, and the cells were incubated with $\mathrm{CM}-\mathrm{H}_{2}$ DCFDA solution for 8 $\min$ at $37^{\circ} \mathrm{C}$ in the dark. After the incubation period, the solution was aspirated, and the cells were rinsed with PBS (phosphate-buffered saline) at $3^{\circ} \mathrm{C}$; then, the cells were lysed in lysis buffer (Tris- $\mathrm{HCl})$. Fluorescence was measured using microplate reader $\left(\lambda_{\text {excitation }}=480 \mathrm{~nm}\right.$, $\lambda_{\text {emission }}=528 \mathrm{~nm}$ ) and was normalised to control cells levels, which were set at $100 \%$ fluorescence. $\mathrm{H}_{2} \mathrm{O}_{2}$ was used as a positive control for cyotoxicity.

\subsection{LC-MS Analysis}

The LC-MS/MS experiments were carried out with an Agilent 1100 LC system. For the chromatographic separation a Zorbax $300 \AA$ Extend-C-18 Column $(2.1 \times 150 \mathrm{~mm})$ was used. The column was held at $95 \%$ solvent A $(0.1 \%$ formic acid in water) and 5\% solvent B $(0.1 \%$ formic acid in $\mathrm{ACN}$ ) for $1 \mathrm{~min}$, followed by an 11 min step gradient from $5 \%$ B to $100 \% B$, then kept for 4 min with $100 \%$ B. Finally, elution was achieved with a linear gradient from $100 \%$ B to $5 \% \mathrm{~B}$ in $2 \mathrm{~min}$. For MS experiments, the capillary voltage was set to $3.5 \mathrm{kV}$ for electrospray ionisation with positive ion polarity.

\subsection{Statistical Analysis}

The data are presented as the mean \pm S.D (standard deviation) and were evaluated using Student's $t$-test.

\section{RESULTS AND DISCUSSION}

\subsection{Total Phenol Contents}

Several studies of the Ulva species revealed that they are good dietary sources of antioxidants [15]. Thus, we evaluated the levels of total phenolic compounds in extracts of $U$. rigida. As shown in Table 1, the ethyl acetate and hydrolised water extracts showed the highest total phenolic contents $(582.93 \pm 0.8$ and $457.12 \pm 4.8 \mathrm{mg} \mathrm{g}^{-1}$, respectively). These data are consistent with previous studies indicated that $U$. rigida extracts produced large amounts of phenolic compounds $[5,6,16]$. Overall, the results showed that phenolic content of all the extracts was quite high.

\subsection{LC-MS/MS Analysis}

LC-MS/MS analyses were performed to characterise the major phenolic compounds contained in $U$. rigida extracts. Several phlorotannins and phenolic acids (peak marked with number in Fig. 1) were tentatively identified using mass spectrometry and compared with literature data. The MS study of the ions allowed the detection of compound 1 with protonated molecular ion $\left([\mathrm{M}+\mathrm{H}]^{+}\right)$at $(\mathrm{m} / \mathrm{z} 127)$ (Table 2). This compound corresponds to phloroglucinol with a fragment at $m / z 108$, which is due to the loss of one molecule of water $(-18)$. The compound 3 with $\left([\mathrm{M}+\mathrm{H}]^{+}\right)$at $m / z 499$, composed by four phloroglucinol units, was also observed, and is tentatively identified as fucodiphloroethol (Table 2, Fig. 1). This tetramers showed a fragmentation pattern with losses of one molecule of water $(-18, m / z 481)$, three methyl ($42, m / z$ 439) and six methyl (- 84, $m / z$ 355), successively. Such phlorotannins characterization were demonstrated in Fucales extracts $[17,18]$.

Table 1. Total phenolic contents of $U$. rigida extracts

\begin{tabular}{|c|c|}
\hline Extract & $\begin{array}{l}\text { Total phenols } \\
\left(\mathrm{mg} \mathrm{GAE} \mathrm{g}^{-1}\right)\end{array}$ \\
\hline Ethyl acetate & $582.93 \pm 0.8$ \\
\hline Methanol & $272.08 \pm 0.2$ \\
\hline Water & $323.7 \pm 1.5$ \\
\hline Hydrolyzed water & $457.12 \pm 4.8$ \\
\hline \multicolumn{2}{|c|}{$\begin{array}{c}\text { The data are expressed as milligram of gallic acid per } \\
\text { gram dry extract. Phenolic contents of ethyl acetate } \\
\text { and hydrolyzed water extracts are significantly } \\
\text { different from those of methanol and water extracts } \\
\left({ }^{* * *} P<0.001\right) \text {. Values are the mean } \pm \text { S.D. (Standard } \\
\text { deviation) ( } n=3) .\end{array}$} \\
\hline
\end{tabular}

In a similar manner, compound 5 with $\left([\mathrm{M}+\mathrm{H}]^{+}\right)$at $\mathrm{m} / \mathrm{z} 747$ can be a fucophloroethols derivatives composed of six units of phloroglucinol. The fragmentation pattern showed losses of one molecule of water $(-18, \mathrm{~m} / \mathrm{z} 729)$, two molecules of water $(-36, m / z 711)$, phloroglucinol and two 
molecules of water $(\mathrm{m} / \mathrm{z} 585,-126-36)$ and one molecule of phloroglucinol, two molecules of water and methyl $(\mathrm{m} / \mathrm{z} 571,-126-36-14)$. A low-intensity product ion was detected $(\mathrm{m} / \mathrm{z} 220)$ which is likely a result of the cleavage of benzene ring structure (Table 2). These results are similar with those obtained in brown seaweeds [19]. The compound $7,\left([\mathrm{M}+\mathrm{H}]^{+}\right.$at $\mathrm{m} / \mathrm{z}$ 743) was identified as dieckol molecules composed of six units of phloroglucinol, with ion peaks observed at $\mathrm{m} / \mathrm{z} 329,311$ and 227 . This might be due to the loss of three phloroglucinol, two water molecules, and one molecule water and six methyl, respectively (Table 2). The compound 8 with $[\mathrm{M}+\mathrm{H}]^{+}$at $\mathrm{m} / \mathrm{z} 375$ and product ion peaks observed at $\mathrm{m} / \mathrm{z} 357,339,249$ and 235 led us to assume that the compound correspond to fucophlorethol composed by three
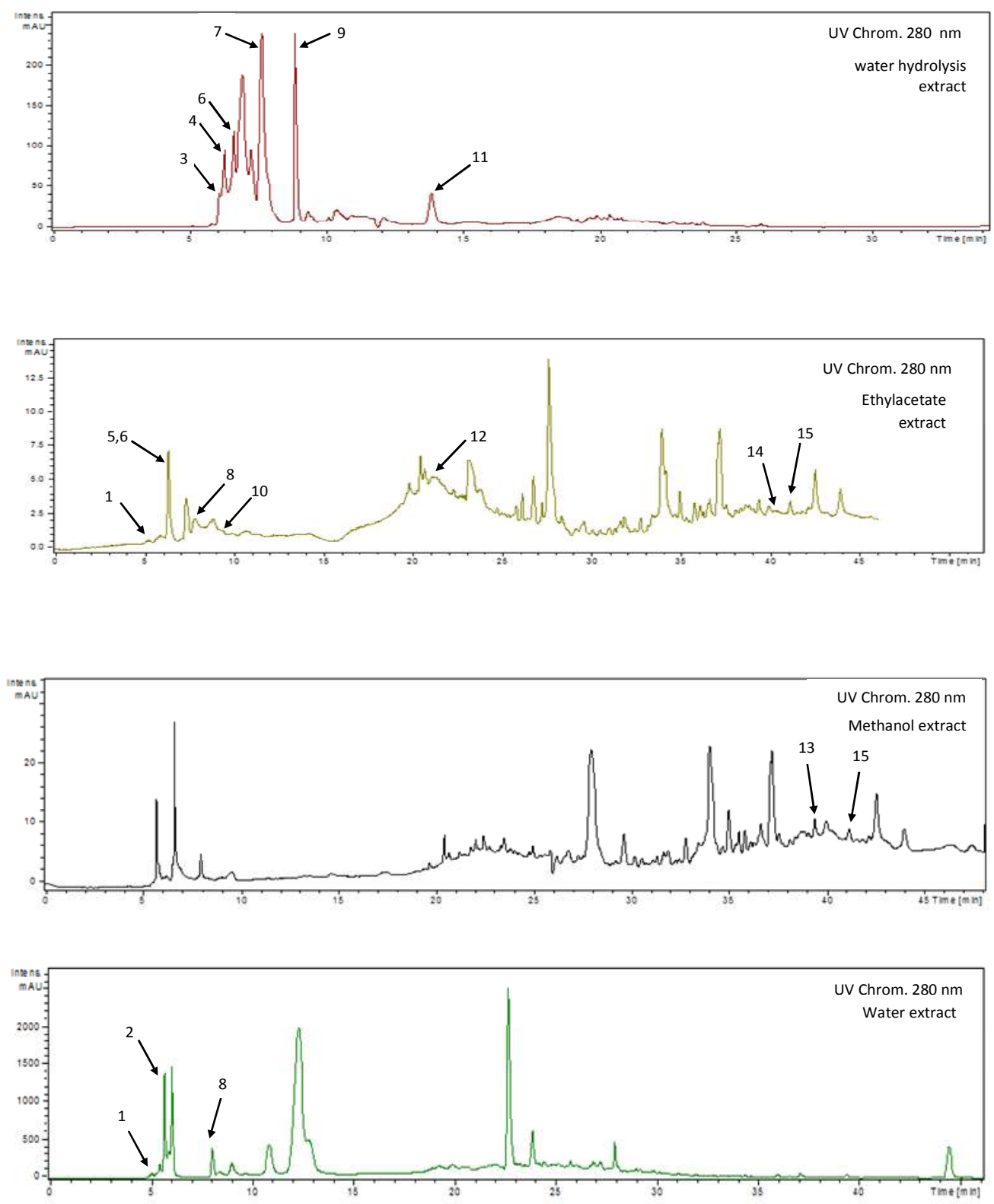

Fig. 1. UV chromatograms of the $U$. rigida extracts recorded at $280 \mathrm{~nm}$ Peaks marked with numbers were identified as in Table 2 
Table 2. Identification of polyphenols in $U$. rigida extracts

\begin{tabular}{|c|c|c|c|c|c|c|}
\hline $\mathbf{N}^{\circ}$ & Compound & $\mathrm{RT}(\mathrm{min})$ & Extract & $\begin{array}{l}\text { UV Amax } \\
\text { (mn) }\end{array}$ & $\begin{array}{l}{[\mathrm{M}-\mathrm{H}]^{-/} /} \\
{[\mathrm{M}-\mathrm{H}]^{+}}\end{array}$ & Major ESI fragments \\
\hline 1 & Phloroglucinol & 5.1 & $a, b$ & 268 & $/ 127$ & 108 \\
\hline 2 & Feruloyl-hexose & 5.5 & b & 326 & 355 & $355,193,135$ \\
\hline 3 & Fucodiphloroethol & 6 & c & 270 & 499 & $481,439,355$ \\
\hline 4 & Vanillic acid & 6.4 & c & 219,261 & 167 & \\
\hline 5 & Fucophloroethols derivatives & 6.4 & a & 280 & 747 & $\begin{array}{l}\overline{7} 29,711,585,571, \\
220\end{array}$ \\
\hline 6 & Quinin acid & 6.6 & $a, c$ & 272 & $/ 193$ & \\
\hline 7 & Dieckol & 7.5 & c & 272 & $/ 743$ & $\overline{3} 29,311,227$ \\
\hline 8 & Fucophloroethol & 8 & $a, b$ & 273 & $/ 375$ & $357,339,249,235$ \\
\hline 9 & Syringic acid & 8.7 & $\mathrm{c}$ & 218,276 & 197 & \\
\hline 10 & phloroeckol & 9.3 & a & 273 & 1497 & $\begin{array}{l}\overline{479}, 451,386,368 \\
258\end{array}$ \\
\hline 11 & Dihydroxybenzoic acid & 14 & $a, c$ & 271 & $/ 155$ & - \\
\hline 12 & Phenylethanol & 21 & a, c & 270 & $/ 123$ & \\
\hline 13 & Dioxinodehydroeckol & 39.1 & $d$ & 275 & /371 & $\overline{3} 29,311,227$ \\
\hline 14 & Eckol & 40.4 & a & 274 & $/ 373$ & $331,313,295$ \\
\hline 15 & Diphloroethohydroxycarmalol & 41.3 & $a, d$ & 272 & $/ 513$ & $495,327,301,257$ \\
\hline
\end{tabular}

phloroglucinol units (Table 2), which is probably due to the loss of one molecule of water, two molecules of water, one molecule of phloroglucinol and one molecule of phloroglucinol and methyl, respectively. Such fragmentation patterns are identified in phlorotannins molecules obtained from Fucus brown algae $[18,20]$. The compound 10 at $\mathrm{m} / \mathrm{z}$ 497 can be a phloroeckol molecule and showed a fragmentation pattern with losses of one water $(\mathrm{m} / \mathrm{z} 479,-18)$, one water and two methyl $(\mathrm{m} / \mathrm{z}$ $451,-18-28$ ) and other fragments at $\mathrm{m} / \mathrm{z} 386$, 368 and 258 (Table 2). The compound 13 at $\mathrm{m} / \mathrm{z}$ 371 correspond to dioxinodehydroeckol. The product ions are $\mathrm{m} / \mathrm{z} 329$ corresponding to a loss of three methyl (-42), 311 (-18) and six methyl $(-84, \mathrm{~m} / \mathrm{z} 227)$, succesively. The compound 14 at $m / z 373$ is suggested to be a polyphenolic compound composed by three phloroglucinol units, possibly a eckol. The fragmentation pattern is $m / z 331$ ( -42 , three methyl), 313 (- 18 , one water) and 295 (- 18, one water), successively. The compound 15 at $\mathrm{m} / \mathrm{z} 513$ is identified as diphloroethohydroxycarmalol, the product ions are successively, $m / z 495$ (- 18 one water), 327 (- 168, twelve methyl) and other low-intensity product ions ( $\mathrm{m} / \mathrm{z} 301$ and 257 ions) which were probably a result of the cleavage of benzene ring structure. Moreover, the chromatogram of $U$. rigida extracts showed the presence of quinic acid and phenolic acids such as dihydroxybenzoic, quinic, siringic, vanillic acids, phenylethanol and feruloyl-hexose which are the main phenolic acids found in U. rigida (Table 2, Fig. 1). The present results indicated for the first time the identification of phlorotannins in Chlorophyta species. These compounds have been reported to occur in brown marine algae and in several families of Angiosperms [21].

\subsection{Free-radical Scavenging Activity}

The radical-scavenging activity of four Ulva rigida extracts were evaluated by DPPH assay based on their ability to quench radicals. The $I_{50}$ values for radical scavenging showed that the ethyl acetate extract had the highest radical scavenging activity with an $\mathrm{IC}_{50}$ value of $0.18 \mu \mathrm{g}$ $\mathrm{mL}^{-1}$ followed by the hydrolysed water $(0.21 \mu \mathrm{g}$ $\left.\mathrm{mL}^{-1}\right)$, water $\left(0.25 \mu \mathrm{g} \mathrm{mL}^{-1}\right)$ and methanol $(0.41$ $\mu \mathrm{g} \mathrm{mL} \mathrm{L}^{-1}$ ) extracts (Fig. 2). As shown in Fig. 2, the antioxidant activities of the ethyl acetate and the hydrolysed water extracts were comparable to that of butylated hydroxytoluene (BHT), which was used as positive reference. Furthermore, the total phenolic compounds showed a positive correlation with the radical-scavenging activity results suggesting that phenolic components constitute the major molecules acting as free radical terminators. These findings are consistent with previous reports that evaluated the antioxidant capacity of $U$. rigida alga $[5,6,16]$.

\subsection{Cytotoxicity and Cytoprotective Effects}

To investigate the cytotoxic effect of $U$. rigida, HeLa cells were treated with concentrations of alga water extract (0 to $1000 \mu \mathrm{g} \mathrm{mL}^{-1}$ ) for $4 \mathrm{~h}$ or 


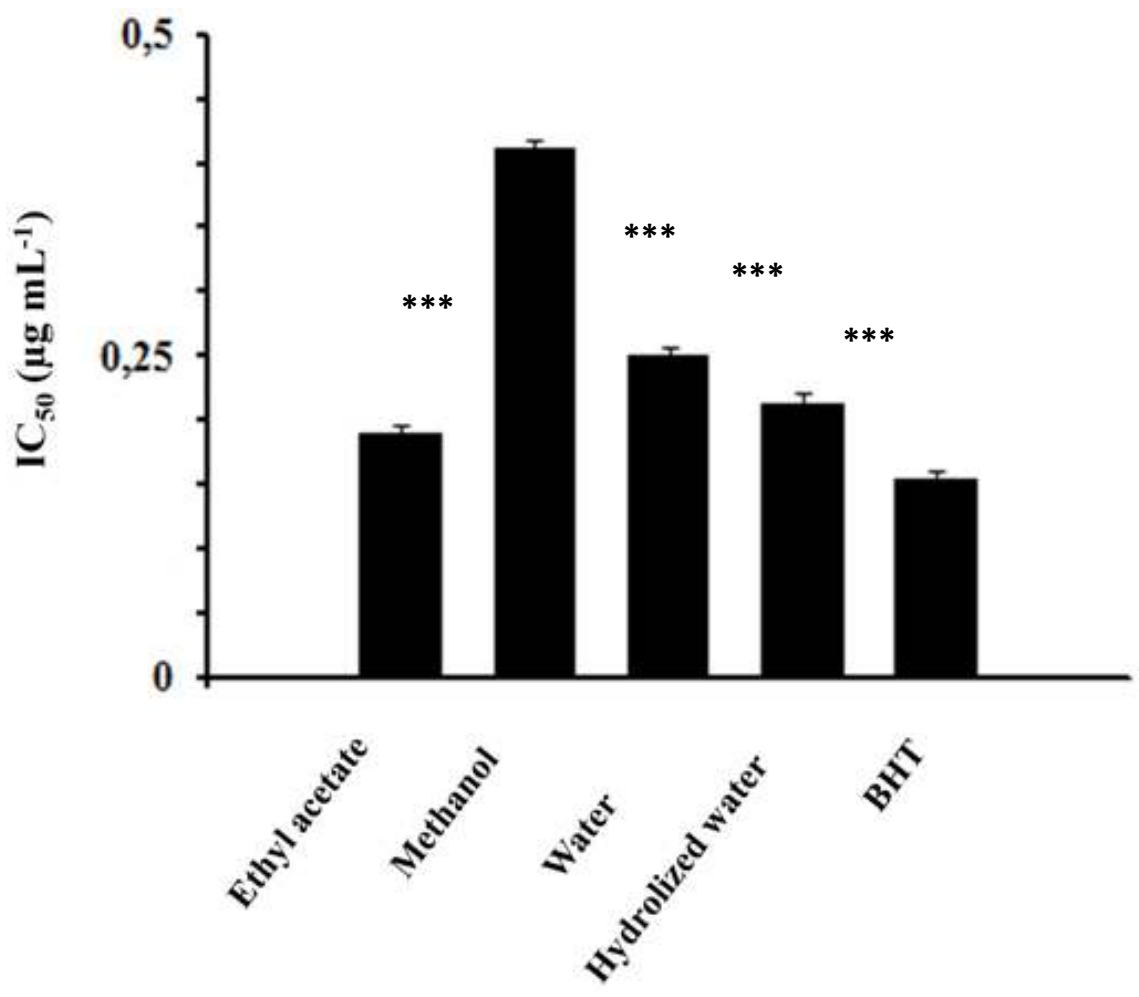

Fig. 2. Radical scavenging activities $\left(\mathrm{IC}_{50}\right)$ of studied $U$. rigida extracts Asterisk indicates a statistically significant difference, $\left({ }^{* * *} P<0.001\right)$

$24 \mathrm{~h}$ and then subjected to a cell viability assay. The results clearly indicate that no significant cell death occured in either algal dose, and the $U$. rigida extract was not toxic even after continuous exposure for a $24 \mathrm{~h}$ period (Fig. 3). Moreover, the cytoprotective action of the $U$. rigida water extract was tested in $\mathrm{H}_{2} \mathrm{O}_{2}$ induced cell death. Exposure to $\mathrm{H}_{2} \mathrm{O}_{2}$ markedly reduced cell viability in a dose-dependent manner, and over $80 \%$ of the cell population was dead after $4 \mathrm{~h}$ treatment with $10000 \mu \mathrm{M} \mathrm{H}_{2} \mathrm{O}_{2}$. However, the co-exposure of cells with $\mathrm{H}_{2} \mathrm{O}_{2}$ and $U$. rigida water extract resulted in an increased percentage of viable cells. As shown in Fig. 3, $U$. rigida extract $(400 \mu \mathrm{g} / \mathrm{ml})$ prevented $\mathrm{H}_{2} \mathrm{O}_{2}-$ induced damage, restoring cell viabilitiy to 74.12 $\left(100 \mu \mathrm{M}\right.$ of $\left.\mathrm{H}_{2} \mathrm{O}_{2}\right), 47.1\left(1000 \mu \mathrm{M}\right.$ of $\left.\mathrm{H}_{2} \mathrm{O}_{2}\right)$ and $20 \%\left(10000 \mu \mathrm{M}\right.$ of $\left.\mathrm{H}_{2} \mathrm{O}_{2}\right)$ versus 45.17, 15.2 and $4.14 \%$. These results indicated that the $U$. rigida extract was not toxic by it self and protects HeLa cells from cytotoxicity and the deleterious effect of $\mathrm{H}_{2} \mathrm{O}_{2}$-mediated oxidative damage. These data are in agreement with our previous study $[16,22]$. The high polyphenol content found in $U$. rigida extracts could be partly responsible for the antioxidant power reported here. Phenolic acids and phlorotannins such as phloroglucinol, eckol, bieckol, dioxinodehydroeckol, and diphloroethohydroxycarmalol are reported to exhibit strong DPPH and ABTS (2,2'-azino-bis (3-ethylbenzothiazoline-6-sulphonic acid) radical scavenging activities $[19,23]$. The antioxidant activities of some phenolic acids and phlorotannins were also investigated in cellular models. In particular, phlorofucofuroeckol, dieckol, diphlorethohydroxycarmalol and dihydrobenzoic acids reduced the level of intracellular reactive oxygen species (ROS) [17-20,24,25]. The phloroglucinol molecule was found to scavenge ROS and increased the catalase-antioxidant enzyme activity [26]. Several reports have shown that phenolic acids (hydroxybenzoic, syringic, salicylic, etc.), phloroglucinol, phlorofucoeckol, eckol and bieckol markedly reduced lipid peroxidation, a hallmark of oxidative stress mediated through the free radicals produced in the cell $[19,27]$. Finally, other studies showed that most phlorotannins possess a remarkable ability to protect cells from death trigged by oxidative stress and prevent damage to biomolecules like DNA $[28,29]$. 


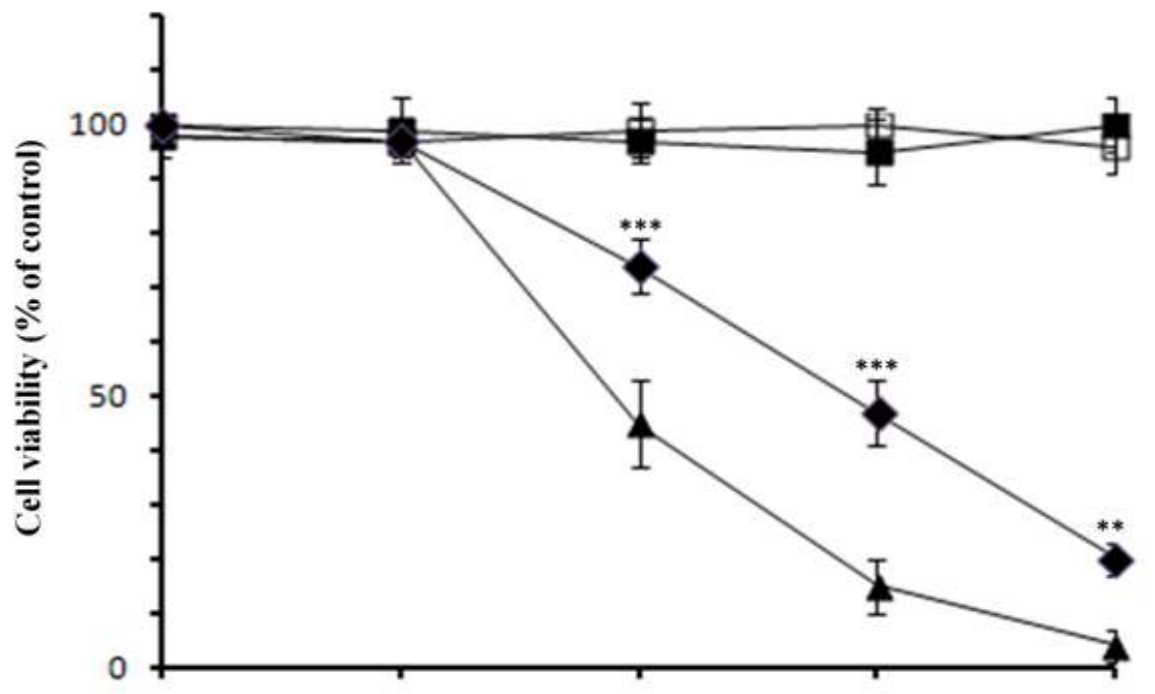

Concentration $\left(\mathrm{H}_{2} \mathrm{O}_{2} \mu \mathrm{M}\right.$ or $U$. rigida $\left.\mu \mathrm{g} / \mathrm{mI}\right)$

Fig. 3. Cytotoxicity and cytoprotective effects of $U$. rigida water extract on $\mathrm{H}_{2} \mathrm{O}_{2}$-induced oxidative cell damage

The cells were treated with U. rigida water extract at 250,350, 500 and $1000 \mu \mathrm{g} \mathrm{mL}^{-1}$ for $4 \mathrm{~h} \mathrm{(-)}$ ) or $24 \mathrm{~h}$ $(-)(\rightarrow)$ represents cells treated with $\mathrm{H}_{2} \mathrm{O}_{2}$ at 10, 100, 1000 and $10000 \mu \mathrm{M}$. (-4) represents cells cotreated with $\mathrm{H}_{2} \mathrm{O}_{2}$ at $10,100,1000$ and $10000 \mu \mathrm{M}$ and $400 \mu \mathrm{g} \mathrm{mL}^{-1}$ of $\mathrm{U}$. rigida water extract and incubated for $4 \mathrm{~h}$. Data are presented as the mean \pm SEM $(n=4)$. Asterisk indicates a statistically significant difference, where $^{* \star} P<0.01$ and ${ }^{* \star} P<0.001$

\section{CONCLUSION}

This paper reports the characterization of the phenolic compounds of $U$. rigida extracts for the first time. On the other hand this preliminary work is the first report mentioned the identification of phlorotannins in green seaweed. In addition, the different extracts exhibited large phenolic contents and potent antioxidant activity. Therefore, $U$. rigida extracts enriched in phenolic molecules may provide a promising source of natural antioxidants, applicable in the pharmaceutical, food and cosmetic industries. However, more studies are needed involving NMR identification and investigation on Ulva species from several origins, in attempt to establish a chemical fingerprint of $U$. rigida phenols.

\section{CONSENT}

It is not applicable.

\section{ETHICAL APPROVAL}

It is not applicable.

\section{COMPETING INTERESTS}

Authors have declared that no competing interests exist.

\section{REFERENCES}

1. Shalaby EA. Algae as promising organisms for environment and health. Plant Signal Behav. 2011;6:1338-1350.

2. Maskarzu M, Nakazoe JI. Production and use of marine algae in Japan. JPN AGR RES Q. 2001;35:281-290.

3. Satpati GG, Pal R. Biochemical composition and lipid characterization of marine green alga U/va rigida-a nutritional approch. JABU. 2011;2:10-13.

4. Taboada C, Millan R, Miguez I. Evaluation of the marine alga Ulva rigida as a food supplement: Effect of intake on intestinal hepatic and renal activities in rats. $\mathrm{J}$ Med Food. 2011;14:161-166.

5. Trigui M, Gasmi L, Zouari I, Tounsi S. Seasonal variation in phenolic composition antibacterial and antioxidant activities of Ulva rigida (Chlorophyta) and assessment of antiacetylcholinesterase potentiel. J App Phycol. 2012;25:319-328. 
6. Yildiz G, Celikler S, Vatan O, Dere S. Determination of the anti-oxidative capacity and bioactive compounds in green seaweed Ulva rigida C. Agardh. Int J Food Prop. 2012;15:1182-1189.

7. Taboada C, Millan R, Miguez I. Composition nutritional aspects and effect on serum parameters of marine algae Ulva rigida. J Sci Food Agr. 2010;90:445-449.

8. Celikler S, Tas S, Vatan O, ZiyanokAyvalik S, Yildiz G, Bilaloglu R. Antihyperglycemic and antigenotoxic potential of Ulva rigida ethanolic extract in the experimental diabetes mellitus. Food Chem Toxicol. 2009;47:1837-1840.

9. Goddard MK, Décordé K, Ventura E, Soteras G, Baccou JC, Cristol JP, Rouanet JM. Polysaccharides from the green alga Ulva rigida improve the antioxidant status and prevent fatty streak lesions in the high cholesterol fed hamster, an animal model of nutritionally-induced atherosclerosis. Food Chem. 2009;115:176-180.

10. Leiro JM, Castro R, Arranz JA, Lamas J. Immunomodulating activities of acidic sulphated polysaccharides obtained from the seaweed Ulva rigida C. Agardh. Int Immunopharmaco. 2007;7:879-888.

11. Castro R, Piazzon MC, Zarra I, Leiro J, Noya M, Lamas J. Stimulation of turbot phagocytes by Ulva rigida C. Agardh polysaccharides. Aquaculture. 2006;254: 9-20.

12. Wolfe $\mathrm{K}, \mathrm{Wu} \mathrm{X}$, Liu $\mathrm{RH}$. Antioxidant activity of apple peels. J. Agric Food Chem. 2003;51:609-614.

13. Dina $A$, Begoña RLM, José Igancio RS, Leandro J, Fadil B, Djebbar A. Antioxidant potential, cytotoxic activity and phenolic content of Clematis flammula leaf extracts. J Med Plants Res. 2011;5:589-598.

14. Anja ST, Cheryl S, Kristin JPS. Application of Alamar blue/5-carboxy fluorescein diacetate acetoxymethyl ester as a noninvasive cell viability assay in primary hepatocytes from rainbow trout. Anaytic Biochem. 2005;344:76-85.

15. Garcia-Casal MN, Ramirez J, Leets I, Pereira AC, Quiroga MF. Antioxidant capacity, polyphenol content and iron bioavailability from algae (Ulva sp., Sargassum sp. and Porphyra sp.) in human subjects. Br J Nutr. 2009;101:7985.

16. Mezghani S, Bourguiba I, Hfaiedh I, Amri M. Antioxidant potential of Ulva rigida extracts: Protection of HeLa cells against $\mathrm{H}_{2} \mathrm{O}_{2}$ cytotoxicity. Biol Bull. 2013; 225:1-7.

17. Lee SH, Jeon YH. Anti-diabetic effects of brown algae derived phlorotannins, marine polyphenols through diverse mechanisms. Fitoterapia. 2013;86:129-136.

18. Ferreres F, Lopes $G$, Gil-Izquierdo A, Andrade PB, Sousa C, Mouga T, Valentao P. Phlorotannin extracts from fucales characterized by HPLC-DAD-ESI-MS ${ }^{n}$ : Approches to hyaluronidase inhibitory capacity and antioxidant properties. Mar Drugs. 2012;10:2766-2781.

19. Balboa EM, Conde E, Moure A, Falqué E, Dorminguez $\mathrm{H}$. In vitro antioxidant properties of crude extracts and compounds from brown algae. Food Chem. 2013;38:1764-1785.

20. Wang $T$, Jonsdottir R, Liu H, Gu L, Kristinsson HG, Raghavan S, Olafsdottir G. Antioxidant capacities of phlorotannins extracted from the brown algae Fucus vesiculosus. J. Agric. Food Chem. 2012;60:5874-5883.

21. Pal Singh I, Bharate SP. Phloroglucinol compounds of natural origin. Nat Prod Rep. 2006;23:558-591.

22. Mezghani M, N'guessan $P$, Carrier A, Amri M. The ethanol precipitate of Ulva rigida protects HeLa cells from hydrogen peroxide-induced apoptosis. J Food and Biochem. 2015;39:48-54.

23. Sroka Z, Cisowski W. Hydrogen peroxide scavenging, antioxidant and anti-radical activity of some phenolic acids. Food Chem Toxicolo. 2003;41:753-758.

24. Kang HS, Chung HY, Kim JY, Son BW, Jung $H A$ and Choi JS. Inhibitory phlorotannins from the edible brown alga Ecklonia stolonifera on total reactive oxygen species (ROS) generation. Arch Pharmacol Res. 2004;27:194-198.

25. Miranda MS, Sato S, Mancini-Filho J. Antioxidant activity of the microalga Chlorella vulgaris cultured on special conditions. Bollettino Chimico Farmaceuticol. 2001;140:165-168.

26. Kang KA, Lee KH, Chae S, Zhang R, Jung MS, Ham YM, Baik JS, Lee NH, Hyun JW. Cytoprotective effect of phloroglucinol on oxidative stress induced cell damage via catalase activation. J Cell Biochem. 2006;97:609-620.

27. Abd El-Baky H, El Baz FK, El-Baroty GS. Production of phenolic compounds from Spirulina maxima microalgae and its protective effects in vitro toward 
hepatotoxicity model. Afr J Pharma Pharmacol. 2009;3:133-139.

28. Heo SJ, Jeon YJ. Evaluation of diphlorethohydroxycarmalol isolated from Ishige okamurae for radical scavneging activity and its protective effect against $\mathrm{H}_{2} \mathrm{O}_{2}$-induced cell damage. Process Biochem. 2009;44:412-418.
29. Ahn GN, Kim KN, Cha SH, Song CB, Lee J, Heo MS, Yeo IK, Lee NH, Jee YH, Kim JS, Heu MS, Jeon YJ. Antioxidant activities of phlorotannins purified from Ecklonia cava on free radical scavenging using ESR and $\mathrm{H}_{2} \mathrm{O}_{2}$-mediated DNA damage. Europ Food Res Technolo. 2007;226:71-79.

(0) 2016 Mezghani et al; This is an Open Access article distributed under the terms of the Creative Commons Attribution License (http://creativecommons.org/licenses/by/4.0), which permits unrestricted use, distribution, and reproduction in any medium, provided the original work is properly cited.

Peer-review history:

The peer review history for this paper can be accessed here: http://sciencedomain.org/review-history/12687 